\title{
chulieieva o. DEVELOPMENT OF DIRECTED REGULATION OF RHEOLOGICAL PROPERTIES OF FIRE RETARDANT COMPOSITE MATERIALS OF ETHYLENE VINYL ACETATE COPOLYMER
}

Об'єктом дослідження є реологічні процеси в'язкого плину полімерних композиційних матеріалів, які не підтримують горіння. Одним з найбільш проблемних питань, що виникають під час переробки полімерних композищійних матеріалів, є підвищена в'язкість, яка потребує збільшення напруг зсуву для досягнення заданої швидкості.

3 метою вирішення цієї проблеми розроблено метод спрямованого регулювання реологічних характеристик полімерних композицій за допомогою введення до їх складу модифікатора. Вивчено вплив модифікатора на процеси в'язкого плину композиційних матеріалів кополімеру етилену з вінілацетатом, які не підтримують горіння та наповнювачів-антипиренів. В дослідженнях використовували кополімер етилену з вінілацетатом. Вміст вінілащетату складає 18 \% та 28 \%; ППР 2,5 г/10 хв. та ППР 5 2/10 хв. Модифікатор - аміносилан. Наповнювачі-антипирени:

- тригідрати оксиду алюмінію з середнім діаметром часточок 1,5 мкм та 3,0 мкм;

- дигідрати оксиду магнію з середнім діаметром часточок 3,0 мкм та 3,7 мкм;

- гідромагнезит з середнім діаметром часточок 1,4 мкм.

Використовуючи метод капілярної віскозиметрії, визначено наступні характеристики:показник плинності розплаву, напруження зсуву, швидкість зсуву, ефективну в'язкість та енергію активації в'язкого плину. Показник плинності розплаву зменшується у разі використання наповнювачів-антипиренів з меншим середнім діаметром часточок. Показник плинності розплаву полімерної композиції з використанням наповнювачів-антипиренів різної хімічної природи та дисперсності підвищується під час введення модифікатора. Для тригідратів оксиду алюмінію в 2-8 рази, для дигідратів оксиду магнію в 2,2-3 рази, для гідромагнезитів в 2,0-2,2 рази. Напруження зсуву та ефективна в'язкість навпаки зменшується під час введення модифікатора в полімерну композицію.

Отримані результати дозволяють підвищувати продуктивність під час переробки розроблених матеріалів за рахунок зниження таких показників, як в'язкість, напруження зсуву, підвищення показників плинності розплаву та швидкості зсуву. Це в свою чергу позитивно вплине на зниження енергозатрат та терміну виготовлення кабельної продукції.

Результати будуть корисними під час розробки рецептур полімерних композицій для кабельної продукції та спрямованого регулювання технологічних показників під час їх переробки.

Ключові слова: композиційні матеріали, кополімер етилену з вінілащетатом, наповнювачі-антипірени, реологічні властивості.

\section{Introduction}

One of the most large-tonnage consumers of electrical insulating polymer materials is the cable industry. In recent years, technical requirements for cable products have increased and, as a consequence, the need to develop new progressive materials, including fire retardant polymer composite materials. The promise of fire retardant composite polyolefin materials is a consequence of their growing use and more stringent fire safety requirements for wires and cables for the power industry, nuclear power, railway transport, construction, etc. That is, the insulation and sheath materials must comply with European standards:

- EN 50363-7: 2005 Insulating, sheathing and covering materials for low voltage energy cables. Part 7: Halogenfree, thermoplastic insulating compounds;
- EN 50363-5: 2005 Insulating, sheathing and covering materials for low voltage energy cables. Part 5: Halogenfree, cross-linked insulating compounds;

- EN 50363-6: 2005 Insulating, sheathing and covering materials for low voltage energy cables. Part 6: Halogenfree, cross-linked sheathing compounds.

Processing of fire retardant polymer composite materials causes very great difficulties, which is due to the high content of fire retardant fillers. The rheological properties of the melt of polymer compositions affect not only the processing conditions, but also the performance characteristics [1]. For example, lowering the viscosity and increasing the shear rate during processing leads to an increase in molecular orientation and improvement of mechanical properties [2]. Therefore, it is directed to regulating the rheological properties by injecting modifying ingredients, 
their dependence on the chemical composition and the number of fillers, as well as the dispersion, is an actual problem.

\section{The object of research and its technological audit}

The object of research is the rheological processes of viscous flow of fire retardant polymeric composite materials. In order to ensure the incombustibility of polymeric compositions have a high degree of filling up to $60 \%$ by weight. One of the most problematic places is the process of processing such compositions. The injection of fillers into the polymer matrix significantly reduces the melt flow index of the polymer, increases the effective viscosity and shear stress. To improve these parameters, a modifier, aminosilane, is added to the polymer composition. A polymer matrix is used - a ethylene vinyl acetate copolymer. Inorganic fillers-fire retardants - aluminum trihydroxide, magnesium hydroxide and hydromagnesite.

\section{The aim and objectives of research}

The aim of the research is studying the specific features of directed control of the rheological properties of composite materials of ethylene-vinyl acetate copolymers, which are fire retardant depending on the composition of the fire retardant fillers, their fractional composition and the amount of the modifier.

To achieve this aim, it is necessary to perform the following tasks:

1. To investigate the dependence of melt flow index of polymer compositions on their composition and properties of ingredients.

2. To establish the regularities of the change in the shear rate from the shear stress, the effective viscosity from the shear rate of polymer compositions with different fire retardants and the effect of the modifier on them.

3. To establish regularities in the change in the activation energy of the viscous flow of polymer compositions from the amount of fire retardants fillers and a modifier.

\section{Research of existing solutions of the problem}

Examination of the existing solutions of the problem shows that one of the means of reducing the combustibility of polymeric materials of polyolefins is the injection of fire retardants fillers in the polymer composition [3]. For this purpose, inorganic fire retardants fillers are used. In real fire conditions PVC plastic compounds, which are elements of cables having a LOI value of up to 40 units, is the source of the release of corrosive $\mathrm{HCl}$ gases and significant smoke. Therefore, in order to solve the problems associated with the release of $\mathrm{HCl}$ and smoke, cable materials have been created that do not release corrosive gases and have a much lower level of smoke emission [4]. These materials not only increase fire resistance by absorbing more heat, but also neutralize acid gases, which leads to a reduction in smoke generation. As the polymer base of these materials, polyolefins are usually used, and magnesium hydroxide, aluminum trihydroxide, hydromagnesites are used as fire retardants. This direction is devoted to a significant number of studies. The mechanical and fire-resistant properties of composite EVA and alumina trihydrate with different particle diameters were studied, and the change in these properties is determined depending on the filler dispersity [5]. The efficiency of the use of calcium hydroxide is shown to increase the fire resistance of medium density polyethylene [6]. TGA/DSC methods are used to study polymer compositions using magnesium hydroxide as a fire retardant, and the heat capacity of these materials is determined [7]. The synergistic effect of aluminum trihydroxide and magnesium hydroxide as fire retardants of EVA is studied. The effectiveness of the use of these fillers has been proved using the methods of structural and calorimetric analysis, as well as the determination of the oxygen index [8]. The effect of aluminum trihydrate and borate melamine on the fire resistance and smoke emission of EVA compositions is studied. Methods of calorimetry, UL-94 and smoke tests show the effectiveness of using alumina trihydroxide and borate melamine in order to reduce the combustibility of polymer compositions [9]. Mechanical properties and fire resistance are studied by the oxygen index of EVA and magnesium dioxide compositions for the analysis of the efficiency of $\mathrm{Mg}(\mathrm{OH})_{2}$ [10]. The effect of a mixture of aluminum trihydroxide and melamine on the fire retardant properties and EVA smoke evolution (vinyl acetate content $60 \%$ by weight, EVA) [11] is evaluated. The effect of nanoclay (organoclays and fire retardants (aluminum trihydroxide and magnesium hydroxide) on the fire resistance of a polymer mixture of ethylene vinyl acetate (EVA) and low density polyethylene (LDPE) is shown [12].

It is established that to ensure the properties of noncombustible composite insulation materials and cable sheaths and better safety of electrical equipment and devices, there should be a very high degree of filling of the polymer matrix with metal hydrates. This can lead to loss of flexibility and low mechanical properties. At the same time, problems arise during processing [13]. Therefore, the study of the effect of modifiers of non-combustible polymer compositions on rheological properties is an important problem. But many issues related to the creation and processing of these materials are still not sufficiently studied.

\section{Methods of research}

Ethylene vinyl acetate copolymers (EVA), which characteristics are given in Table 1, are studied, as well as fire retardant fillers, which are used aluminum trihydroxide, magnesium hydroxide, magnesite mixture and hydromagnesite. The characteristics of fire retardant fillers are given in Table 2. Modifier - aminosilane (N-(3-trimethoxysilane) propylbutylamine).

The characteristics are given in Table 3 .

Table 1

Characteristics of copolymers of ethylene with vinyl acetate (EVA)

\begin{tabular}{|l|c|c|}
\hline \multicolumn{1}{|c|}{ Indicator } & EVA 1 & EVA 2 \\
\hline Density, kg/m ${ }^{3}$ & 939 & 951 \\
\hline Melt flow index, $2.16 \mathrm{~kg}, \mathrm{~g} / 10 \mathrm{~min}$ & 2.5 & 5 \\
\hline Vinyl acetate content, \% & 18 & 28 \\
\hline
\end{tabular}




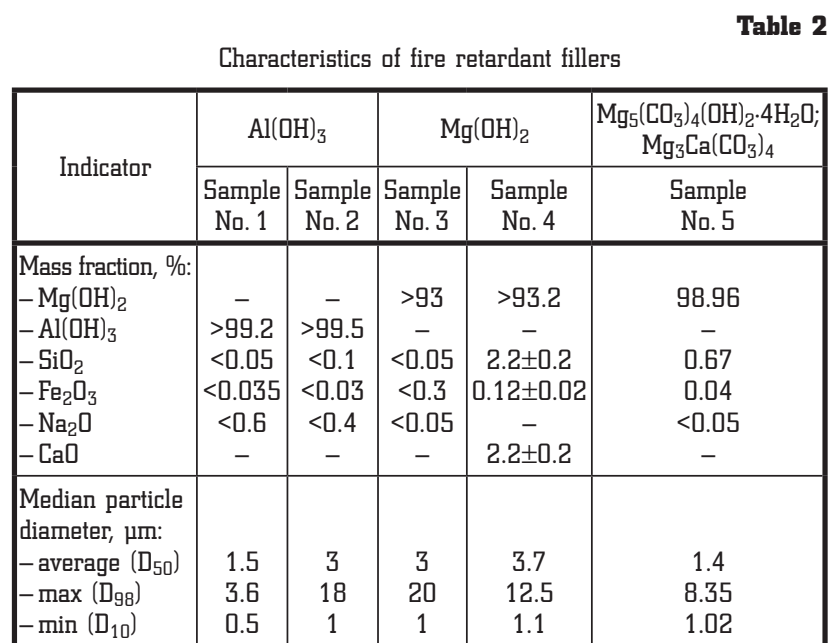

Table 3

Characteristics of aminosilane

\begin{tabular}{|l|c|}
\hline \multicolumn{1}{|c|}{ Indicator } & Value \\
\hline Density, $\mathrm{kg} / \mathrm{m}^{3}, 20^{\circ} \mathrm{C}$ & 947 \\
\hline Dynamic viscosity, $\mathrm{mPa} \cdot \mathrm{s}, 20^{\circ} \mathrm{C}$ & 2.5 \\
\hline Boiling point, ${ }^{\circ} \mathrm{C}$ & 260 \\
\hline
\end{tabular}

Experimental samples of EVA polymer compositions with different percentages of fillers-fire retardants and a modifier in each composition are made by rolling method at a temperature of $(443 \pm 5) \mathrm{K}$ for (7-10) min. The rollers have a friction of 1.5 .

The ingredients of the polymer compositions are weighed on a scale to an accuracy of $0.001 \mathrm{~g}$ and consistently loaded onto the rollers. Work roller temperature is $(443 \pm 5) \mathrm{K}$. Cold roller temperature is $(438 \pm 5) \mathrm{K}$. Samples roll 3 minutes on the gap $0.4-0.5 \mathrm{~mm}$. Then the gap is adjusted to $2 \mathrm{~mm}$. In the process of rolling periodically cut at least 2 times a minute. The last minute rolling is without cuts.

The samples are conditioned at a temperature of $(293 \pm 2) \mathrm{K}$ for at least 24 hours.

Investigation of the rheological properties of polymeric materials is carried out by capillary viscometry on the IIRT-AM instrument (Thermoplastic Melt Index Meter) (Ukraine). The results are processed and graphics are plotted using Microsoft Office Excel 2007 software.

The adequacy of the regression equation is checked by checking the statistical significance of the coefficient of determination $R^{2}$ by the $F$-criterion determined by the formula [14]:

$$
F_{p}=\frac{R^{2}}{1-R^{2}} \cdot \frac{n-m-1}{m},
$$

where $n$ - the number of observations; $m$ - the number of factors in the regression equation.

\section{Research results}

The rheological properties of the EVA are estimated, which is filled primarily with the melt flow index (MFI), according to EN 60811-511:2012. Electric and optical fiber cables - Test methods

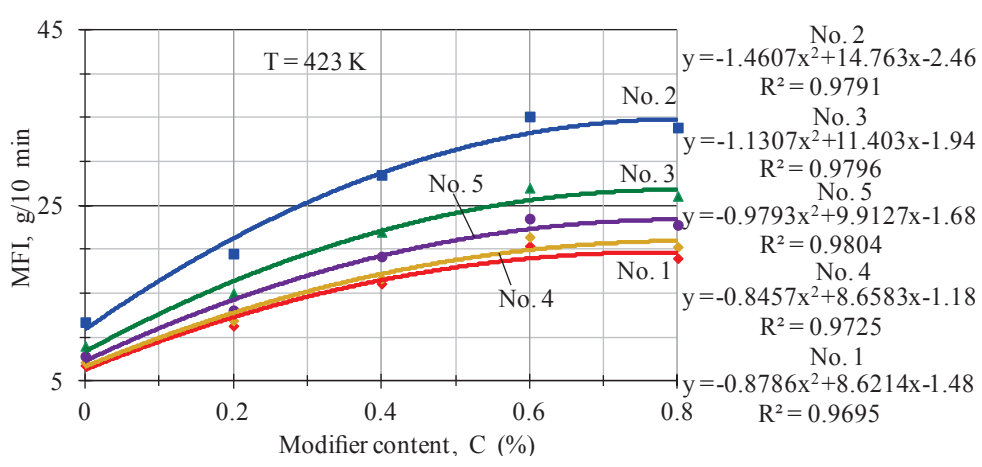

Fig. 1. Dependence of the melt flow index (MFI) of polymer compositions of EVA 1 on the amount of the modifier (fire retardants sample No. 1-5)

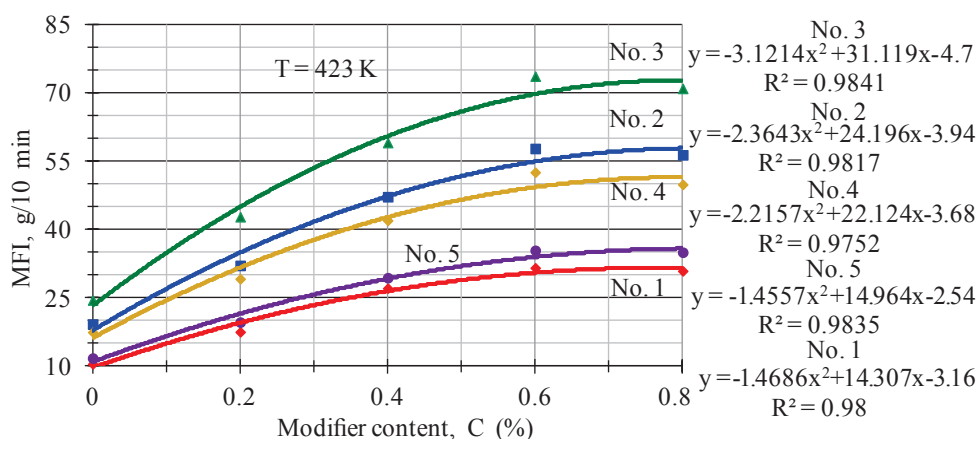

Fig. 2. Dependence of the melt flow index (MFI) of polymer compositions of EVA 2 on the amount of the modifier (fire retardants sample No. 1-5) 
The displacement rate was determined by the formula:

$$
\dot{\gamma}=\frac{4 \cdot Q}{\pi \cdot r^{3}},
$$

where $\gamma$ - the shear rate, $\mathrm{s}^{-1} ; Q$ - material consumption, $\mathrm{cm}^{3} / \mathrm{s}(Q=\pi \cdot R \cdot 2 \cdot h$, where $h$ is the stationary velocity of the piston immersion, $\mathrm{cm} / \mathrm{s} ; R$ - cylinder radius, $\mathrm{cm}) ; r$ - capillary radius, $\mathrm{cm}$.
The effective viscosity is determined by the formula:

$$
\eta_{e f}=\frac{\tau}{\dot{\gamma}}
$$

where $\eta_{\text {eff }}$ - the effective viscosity, Pa-s.

Graphs of the logarithmic dependence of shear stress on shear rate and effective viscosity on shear rate are plotted.

The results are shown in Fig. 3-6.

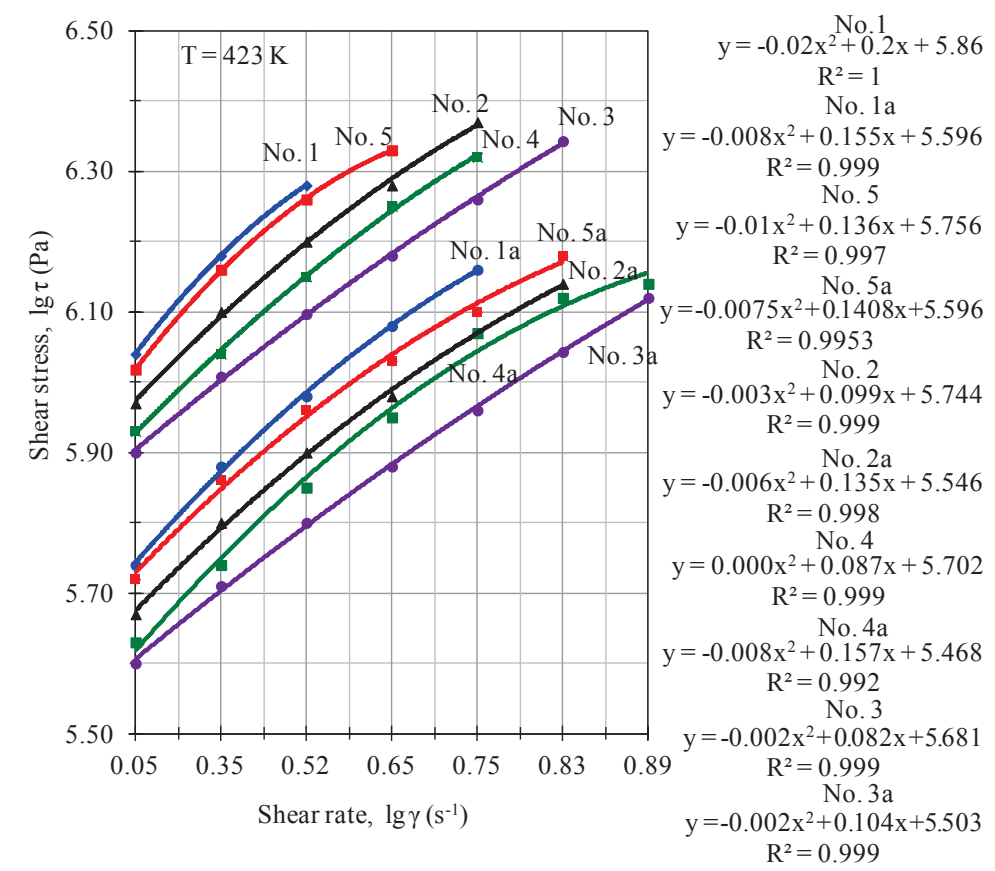

Fig. 3. Dependence of the shear rate based on the shear stress of the polymer based on EVA 1 and fire retardants (5ample No. 1-5) without a modifier and a modifier in the amount of $0.6 \%$ (Sample No. 1a-5a)

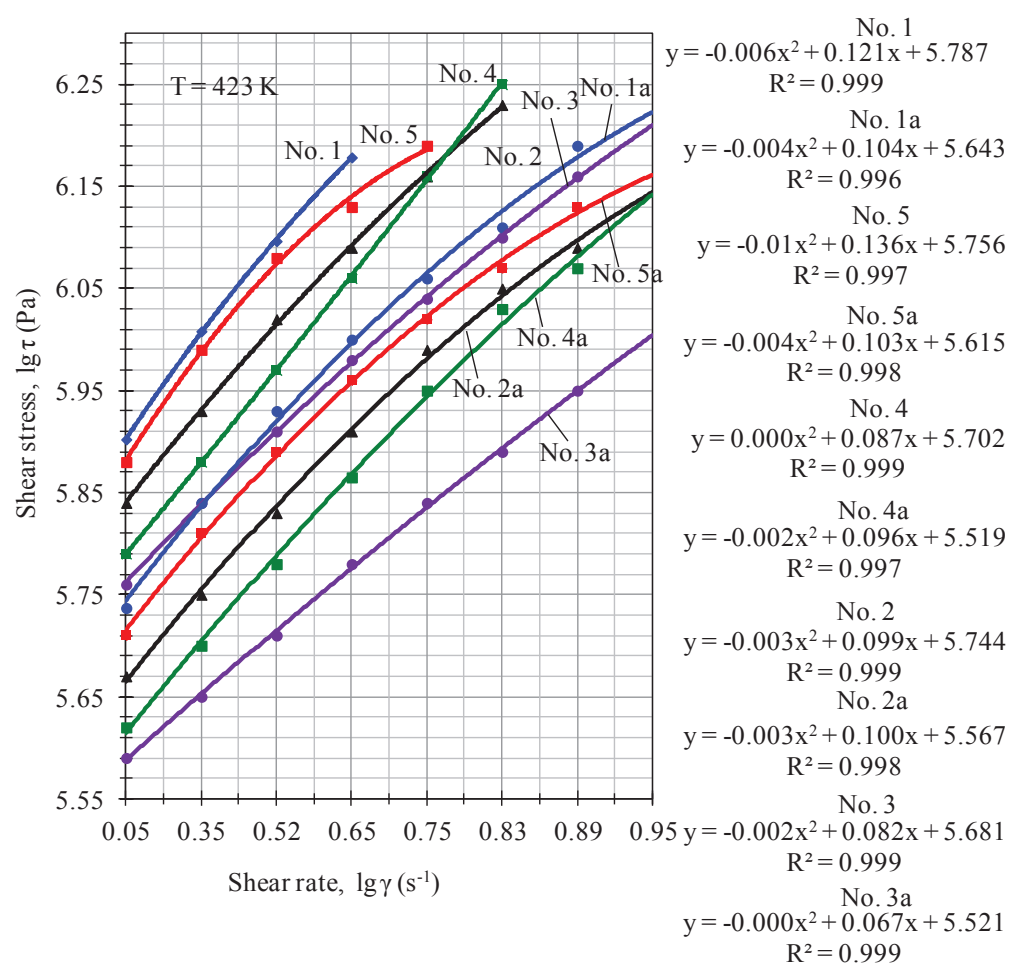

Fig. 4. Dependence of the shear rate on the shear stress of polymer compositions based on EVA 2 and fire retardants (5ample No. 1-5) without a modifier and with a modifier in an amount of $0.6 \%$ (5ample No. 1a-5a) 


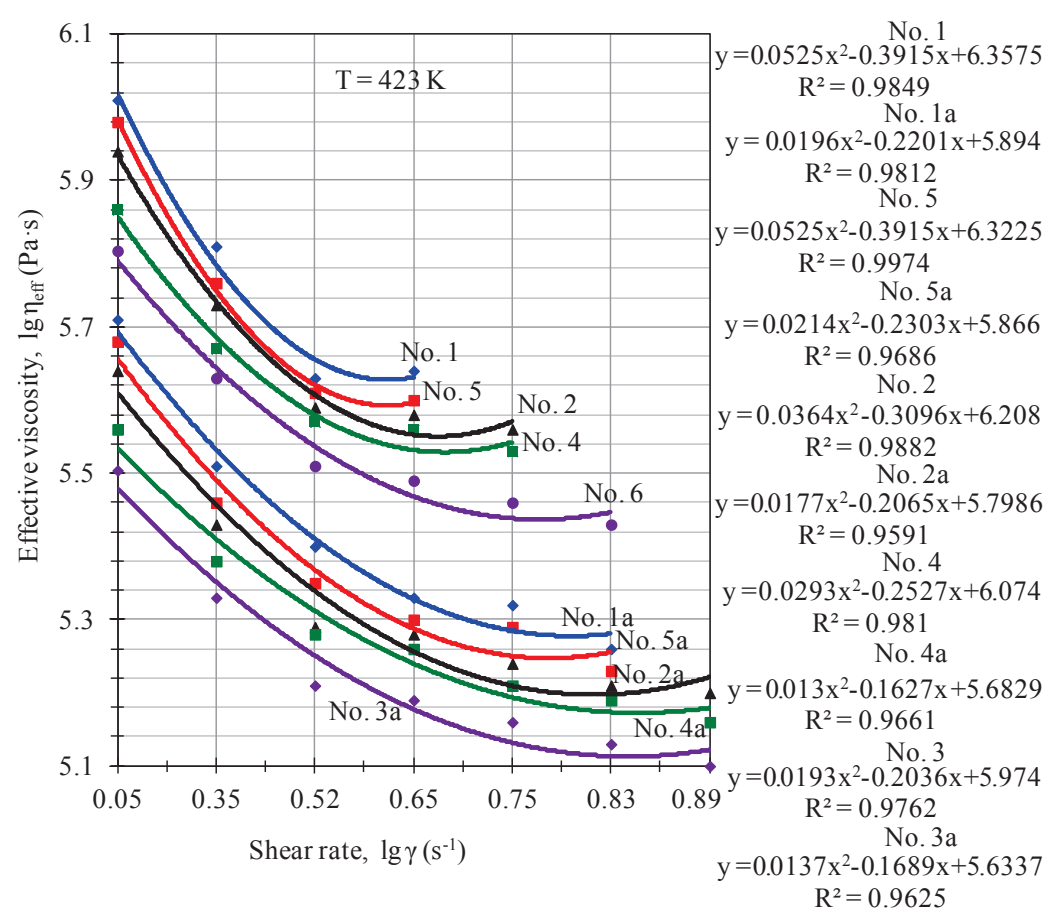

Fig. 5. Dependence of the effective viscosity on the shear rate of polymer compositions based on EVA 1 and fire retardants (5ample No. 1-5) without a modifier and with a modifier of $0.6 \%$ (Sample No. 1a-5a)

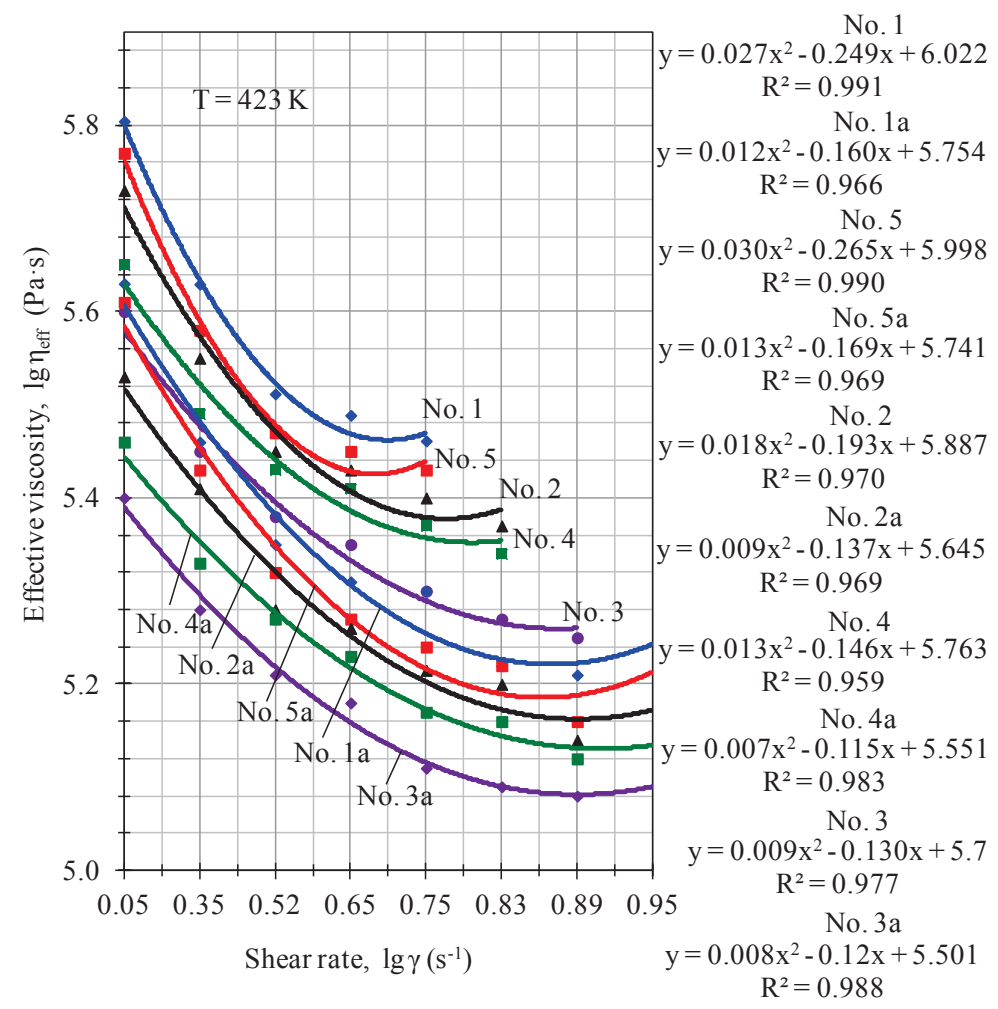

Fig. 6. Dependence of the effective viscosity on the shear rate of polymer compositions based on EVA 2 and fire retardants (5ample No. 1-5) without a modifier and with a modifier in an amount of $0.6 \%$ (5ample No. 1a-5a)

In order to estimate the energy that is necessary for the transition of the system to the so-called transition state, that is, when disruption and bonding are balanced, it is necessary to calculate the activation energy.

The activation energy of viscous flow is determined by the formula [18]:

$$
E_{a c}=\frac{R \cdot T_{1} \cdot T_{2} \cdot \ln \left(M F I_{1} / M F I_{2}\right)}{T_{2}-T_{1}},
$$

where $T$ - the measurement temperature, $\mathrm{K} ; M F I_{1}$ and $M F I_{2}-$ melt flow indices according to $T_{1}$ and $T_{2}, \mathrm{~g} / 10 \mathrm{~min}$; $R$ - the universal gas constant, $R=8.314 \mathrm{~J} / \mathrm{mol}$. 
The results are shown in Fig. 7,8 .

Research results (Fig. 7, 8) determine the energy barriers that are overcome in the elementary act of flow, depending on the type of fillers-fire retardants and the amount of modifier.

As can be seen from the graphs (Fig. 1, 2), the MFI when using EVA 2 are higher than in the case of using EVA 1 with a lower content of vinyl acetate. A noticeable decrease in MFI occurs when EVA 1 is used, which is filled with any fire retardant.

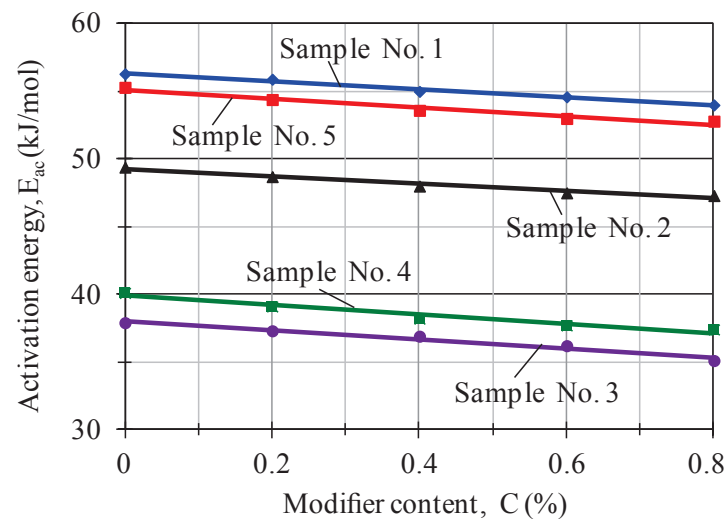

$$
\begin{gathered}
\text { No. } 1 \\
y=-0.59 x+56.93 \\
R^{2}=0.9856 \\
\text { No. } 5 \\
y=-0.64 x+55.74 \\
R^{2}=0.9552 \\
\text { No. } 2 \\
y=-0.54 x+49.8 \\
R^{2}=0.963 \\
\text { No. } 3 \\
y=-0.67 x+38.69 \\
R^{2}=0.9658 \\
\text { No. } 4 \\
y=-0.68 x+40.54 \\
R^{2}=0.9514
\end{gathered}
$$

Fig. 7. Dependence of the activation energy of the viscous flow of polymer compositions based on EVA 1 and fire retardants (sample No. 1-5) on the amount of the modifier

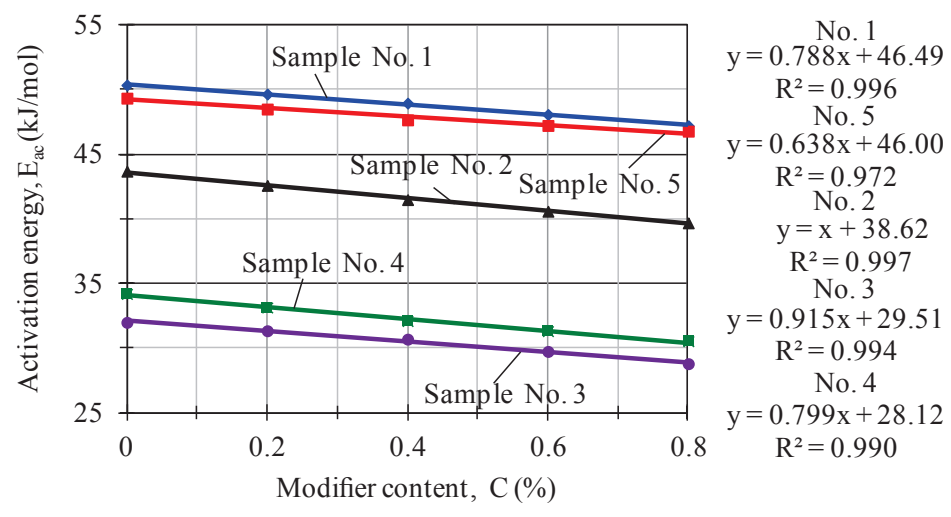

Fig. 8. Dependence of the activation energy of the viscous flow of polymer compositions based on EVA 2 and fire retardants (sample No. 1-5) on the amount of the modifier

An analysis of the obtained results also shows a significant reduction in MFI using alumina trihydrate with a smaller particle diameter. The same dependence is observed in the case of the use of magnesium hydroxide. Hydromagnesite occupies the middle position between sample No.1 and No. 2 of aluminum trihydroxide.

MFI is significantly increased when using a modifier for all polymer compositions.

From Fig. 3 it is possible to see that the flow curves shift upward for the polymer compositions of EVA 1. When using fire retardant fillers with a smaller average particle diameter of aluminum and magnesium hydroxide, greater stresses are required to achieve a given shear rate. The shear stress is significantly reduced when a modifier is injected into the polymer compositions.

Let's consider the results of rheological studies of polymer compositions of EVA 2 (Fig. 4) at the same values of the shear rate. The greatest shear stress has composion 1, which includes EVA 2 and aluminum trihydroxide mple No. 1) with a smaller dispersion and an average hydroxide (sample No, 4). Flow curves using

On the graphs of the effective viscosity on the shear te (Fig. 5,6), an increase in the effective viscosity with decreasing average particle diameter of the fire retardant fillers particles is observed. For polymer compositions using aluminum trihydroxide and hydromagnesite (compositions $1,2,5$ ), the effective viscosity is significantly higher than the polymer compositions 3, 4 in which magnesium hydroxide is used. The effective viscosity is reduced for all polymer compositions when the modifier is injected (curves 1a, 2a, 3a, 4a, 5a).

The most effective viscosity is observed in polymer compositions with the lowest dispersion of fillers.

From Fig. 7, 8, the lowest values of the activation energy have polymer compositions using magnesium hydroxide, large ones using aluminum trihydroxide and hydromagnesite. At the same time, activation energies of polymer compositions decrease with increasing amount of modifier.

Thus, the rheological properties of non-combustible polymer depend on the melt flow rate of the polymer matrix, the chemical composition of the hydrate of metal oxides hydrate, the hydromagnesites and the modifier.

\section{SWOT analysis of research results}

Strengths. The obtained results allow to increase the productivity during processing of the developed materials due to the decrease of such parameters as viscosity, shear stress, increase in the melt flow parameters and shear rate. This, in turn, will positively affect the reduction of energy costs and the production time of cable products.

Weaknesses. Ingredients of polymer compositions are not produced in Ukraine, it is necessary to conduct import purchases.

Opportunities. The results will be useful in the development of formulations of polymer compositions for cable products and the directed regulation of technological parameters during their processing.

Threats. It is necessary to master the technological process of manufacture, training personnel to conduct the technological process.

\section{Conclusions}

1. It has been found that the melt flow index is a copolymer of ethylene with vinyl acetate, the composition and dispersity of aluminum trihydroxide, magnesium hydroxide, hydromagnesite affect the melt flow index of the polymer compositions. An ethylene vinyl acetate copolymer having a greater melt flow index provides a greater melt flow index of the filled polymer composition for all fire retardant 
fillers. Aluminum trihydoxide and magnesium hydroxide with a smaller average particle size reduce the melt flow index of the polymer compositions. A significant increase in MFI is due to the injection of a modifier. The melt flow index of the polymer composition using fire retardant fillers of different chemical nature and dispersity increases with the injection of the modifier. For aluminum trihydroxide 2-8 times, for magnesium hydroxide 2.2-3 times, for hydromagnesites 2.0-2.2 times.

2. It is shown that the use of fire-retardant fillers of different composition and dispersity affects the change in shear stress and effective viscosity to achieve a given shear rate. The shear stress and the effective viscosity increase for polymer compositions containing fire retardant fillers $(1,4)$ with a smaller average particle size. These values are significantly reduced when the modifier is injected. The shear stress decreases from 6.04 $\mathrm{Pa}$ to $5.5 \mathrm{~Pa}$ at small shear rates, and from $6.35 \mathrm{~Pa}$ to $6.12 \mathrm{~Pa}$ at high shear rates. The effective viscosity decreases from 5.94 Pa-s to 5.5 Pa.s with slightly higher shear rates and from $5.62 \mathrm{~Pa} \cdot \mathrm{s}$ to $5.12 \mathrm{~Pa} \cdot \mathrm{s}$ at higher shear rates.

3. It has been established that the concentration of the filler practically does not change the value of the activation energy of the polymer compositions, while the nature and dispersity of the fire retardants fillers has a significant swim in the change in the activation energy. The activation energy increases for polymer compositions with aluminum oxide trihydrate, magnesium hydroxide with a smaller average particle diameter. Depending on the composition of the fire retardant fillers, the activation energy increases in the order of the samples: 3, 4, 2, 5, 1. Simultaneously, the activation energy decreases when the modifier is injected from $56 \mathrm{~kJ} / \mathrm{mol}$ to $29 \mathrm{~kJ} / \mathrm{mol}$, depending on the polymer composition.

Thus, studies have shown the possibility of directional control of the polymer compositions by such means as the use of different polymer matrices, the qualitative and fractional composition of fire retardant fillers, and the injection of a modifier into the polymer composition.

\section{References}

1. Peshkov I. B. Materialy kabel'nogo proizvodstva. Moscow: Mashinostroenie, 2013. $456 \mathrm{p}$.

2. Chang D. Kh. Reologiya v protsessakh pererabotki polimerov / ed. by Vinogradov G. V., Fridman M. L. Moscow: Khimiya, 1979. 368 p.

3. Tirelli D. Antipireny dlya kompozitov // The Chemical Journal. 2013. No. 1-2. P. 42-45.

4. Obzor mineral'nykh antipirenov-gidroksidov dlya bezgalogennykh kabel'nykh kompozitsiy // Kabel'-news. 2009. No. 8. P. 41-43.
5. Mechanical and fire retardant properties of EVA/clay/ATH nanocomposites - Effect of particle size and surface treatment of ATH filler / Cardenas M. A. et al. // Polymer Degradation and Stability. 2008. Vol. 93, No. 11. P. 2032-2037. doi:10.1016/ j.polymdegradstab.2008.02.015

6. Calcium-based hydrated minerals: Promising halogen-free flame retardant and fire resistant additives for polyethylene and ethylene vinyl acetate copolymers / Laoutid F. et al. // Polymer Degradation and Stability. 2013. Vol. 98, No. 9. P. 1617-1625. doi:10.1016/j.polymdegradstab.2013.06.020

7. Thermal study of low-grade magnesium hydroxide used as fire retardant and in passive fire protection / Formosa J. et al. // Thermochimica Acta. 2011. Vol. 515, No. 1-2. P. 43-50. doi:10.1016/ j.tca.2010.12.018

8. Effect of Amino alcohol functionalized polyethylene as compatibilizer for LDPE/EVA/clay/flame-retardant nanocomposites / Lujan-Acosta R. et al. // Materials Chemistry and Physics. 2014. Vol. 146, No. 3. P. 437-445. doi:10.1016/j.matchemphys.2014.03.050

9. The combination of aluminum trihydroxide (ATH) and melamine borate $(\mathrm{MB})$ as fire retardant additives for elastomeric ethylene vinyl acetate (EVA) / Hoffendahl C. et al. // Polymer Degradation and Stability. 2015. Vol. 115. P. 77-88. doi:10.1016/ j.polymdegradstab.2015.03.001

10. Characterization of poly(ethylene-co-vinyl acetate) (EVA) filled with low grade magnesium hydroxide / Fernandez A. I. et al. // Polymer Degradation and Stability. 2009. Vol. 94, No. 1. P. 57-60. doi:10.1016/j.polymdegradstab.2008.10.008

11. Decomposition mechanism of fire retarded ethylene vinyl acetate elastomer (EVA) containing aluminum trihydroxide and melamine / Hoffendahl C. et al. // Polymer Degradation and Stability. 2015. Vol. 113. P. 168-179. doi:10.1016/j.polymdegradstab.2014.09.016

12. Effects of nanoclay and fire retardants on fire retardancy of a polymer blend of EVA and LDPE / Zhang J. et al. // Fire Safety Journal. 2009. Vol. 44, No. 4. P. 504-513. doi:10.1016/ j.firesaf.2008.10.005

13. Chang M.-K., Hwang S.-S., Liu S.-P. Flame retardancy and thermal stability of ethylene-vinyl acetate copolymer nanocomposites with alumina trihydrate and montmorillonite // Journal of Industrial and Engineering Chemistry. 2014. Vol. 20, No. 4. P. 1596-1601. doi:10.1016/j.jiec.2013.08.004

14. 14. Makarova N. V. Statistika v Excel: handbook. Moscow: Finansy i statistika, 2002. 368 p.

15. 15. Malkin A. Ya., Isaev A. I. Reologiya. Kontseptsii, metody, prilozheniya. Moscow: Professiya, 2007. 560 p.

16. 16. Shakh V. Spravochnoe rukovodstvo po ispytaniyam plastmass i analizu prichin ikh razrusheniya / ed. by Malkin A. Ya. Saint Petersburg: Nauchnye osnovy i tekhnologii, 2009. 732 p.

17. 17. Teplofizicheskie i reologicheskie kharakteristiki polimerov: handbook / ed. by Lipatov Yu. S. Kyiv: Naukova dumka, 1977. $244 \mathrm{p}$.

18. 18. Mukhin N. M. Opredelenie reologicheskikh i fiziko-mekhanicheskikh svoystv polimernykh materialov: handbook. Ekaterinburg: UGLTU, 2011. 33 p.

Chulieieva Olena, PhD, Director of the Science and Technology Center, PJSC «YUZHCABLE WORKS», Kharkiv, Ukraine, e-mail: echuleeva@ukr.net, ORCID: http://orcid.org/0000-0002-7310-0788 